\title{
The effect of soil inoculants on seed germination of native and invasive species
}

\begin{tabular}{|c|c|}
\hline Journal: & Botany \\
\hline Manuscript ID & cjb-2016-0248.R2 \\
\hline Manuscript Type: & Article \\
\hline Date Submitted by the Author: & 29-Nov-2016 \\
\hline Complete List of Authors: & $\begin{array}{l}\text { Balshor, Bailey; University of California, Irvine, Center for Environmental } \\
\text { Biology } \\
\text { Garrambone, Matt; University of California, Irvine, Center for } \\
\text { Environmental Biology } \\
\text { Austin, Paige; University of California, Irvine, Center for Environmental } \\
\text { Biology } \\
\text { Balazs, Kathleen; University of California, Irvine, Center for Environmental } \\
\text { Biology } \\
\text { Weihe, Claudia; University of California, Irvine, Ecology and Evolutionary } \\
\text { Biology } \\
\text { Martiny, Jennifer; University of California, Irvine, Ecology and Evolutionary } \\
\text { Biology } \\
\text { Huxman, Travis; University of California, Irvine, Center for Environmental } \\
\text { Biology } \\
\text { McCollum, Johannah; University of California, Irvine, Center for } \\
\text { Environmental Biology } \\
\text { Kimball, Sarah; University of California, Irvine, Center for Environmental } \\
\text { Biology }\end{array}$ \\
\hline Keyword: & $\begin{array}{l}\text { soil microbial community, native and invasive species, seed germination, } \\
\text { restoration, soil inocula }\end{array}$ \\
\hline
\end{tabular}




\title{
The Effect of Soil Inoculants on Seed Germination of Native
}

\author{
and Invasive Species
}

\section{Bailey J. Balshor, Matthew S. Garrambone, Paige Austin, Kathleen R. Balazs, \\ Claudia Weihe, Jennifer B.H. Martiny, Travis E. Huxman, Johannah R. McCollum, and Sarah Kimball}

1. Bailey J. Balshor, Center for Environmental Biology, University of California, Irvine, CA 92697-1450, bbalshor@uci.edu

2. Matthew S. Garrambone, Center for Environmental Biology, University of California, Irvine, CA 926971450,mgarramb@uci.edu

3. Paige Austin, Center for Environmental Biology, University of California, Irvine, CA 92697-1450, paustin@uci.edu

4. Kathleen R. Balazs, Center for Environmental Biology, University of California, Irvine, CA 92697-1450. Current address: Northern Arizona University, Department of Biological Sciences, Flagstaff, AZ 860115640, kathleen.balazs@gmail.com

5. Claudia Weihe, Department of Ecology and Evolutionary Biology, University of California, Irvine, CA 92697, cweihe@uci.edu

6. Jennifer B.H. Martiny, Department of Ecology and Evolutionary Biology, University of California, Irvine, CA 92697,jmartiny@uci.edu

7. Travis E. Huxman, Center for Environmental Biology, University of California, Irvine, CA 92697-1450, thuxman@uci.edu

8. Johannah R. McCollum, Center for Environmental Biology, University of California, Irvine, CA 926971450. Current Address: Department of Wildlife, Fisheries, and Aquaculture, Mississippi State University, Starkville, MS 39762,jreed.mccollum@gmail.com

9. Sarah Kimball, Corresponding Author, Center for Environmental Biology, University of California, Irvine, CA 92697-1450, skimball@uci.edu 


\begin{abstract}
Successful re-introduction of native species through ecological restoration requires understanding the complex process of seed germination. Soil microbes play an important role in promoting native establishment, and are often added to restoration sites during seed sowing. We tested the role of soil and lab-grown bacterial inoculants on germination timing and percent germination for nineteen species of plants commonly found in coastal California. Each species exhibited a different response to inoculant treatments, but overall time-to-germination was longer and percent germination was lower with soil inoculant compared to control or other treatments. The invasive species in our study had the highest percent germination of all species and germinated faster than all native shrubs. Germination timing was negatively correlated with percent germination and with seed weight. Our results suggest that lab grown inoculant and chemical treatment are effective at increasing germination in some native species, while soil inoculant is not. Given differences in germination timing between native and invasive species, restoration practitioners could consider using herbicide to treat areas seeded with native shrubs immediately following germination of invasive species without harming most natives, although germination timing and herbicides need further study in relation to microbial effects on seed germination.
\end{abstract}

Keywords: Soil microbial community; native and invasive species; seed germination; restoration; soil inocula; PPFM 


\section{Introduction}

Ecological restoration of heavily degraded plant communities frequently involves removing non-native, invasive species and adding natives, either by sowing native seeds or by planting seedlings of native plants (Kimball et al. 2015; SER 2004; Yurkonis et al. 2008). Thus, successful re-introduction of natives requires understanding the germination biology of common native and invasive species (Vaughn and Young 2015; Wainwright et al. 2012). Germination is a particularly vulnerable stage in the plant life cycle, representing the transition from the seed to an actively-growing seedling. Supporting this transition is key to the successful establishment of newly introduced native species, and disrupting this transition could provide a means to reduce the abundance of invasive species (Jimenez-Alfaro et al. 2016). Invasive species are able to outcompete or displace native species, and the timing of germination, along with the overall proportion of seeds that germinate (hereafter percent germination) seem to play an important role in their success (Guthrie et al. 2016; Vaughn and Young 2015).

The community of microbial organisms (fungi and bacteria) that live in the soil may also influence timing and percentages of seed germination, and clarifying their effect will help with developing successful restoration techniques (Kulmatiski et al. 2006; Mordecai 2012). The role of the microbial soil community in restoration ecology has been most studied in terms of its influence on plant establishment and health. For example, mycorrhizal fungi inoculants are often a supplement to native seed in restoration projects because of the fungi's ability to form mutualistic associations with many plant species, improving nutrient uptake by plant roots (Allen et al. 2003; Aprahamian et al. 2016; Thrall et al. 2005). Likewise, soil bacterial communities can promote plant growth by fixing atmospheric nitrogen, therefore restoration practitioners may 
include leguminous natives in their projects to improve soil fertility (Perez-Fernandez et al. 2016; Requena et al. 2001). Beneficial soil microbes such as mycorrhizae and rhizobia may prefer particular plant species, suggesting that the source of microbial inoculum will influence its effectiveness in restoration efforts. Indeed, a meta-analysis of mycorrhizal inoculation showed that the best results came from locally sourced inocula (Maltz and Treseder 2015). Invasive plant species can also alter soil microbial community structure and function (Kourtev et al. 2003). These changes may result in a positive feedback mechanism in which the non-natives associate with different microbes, changing the soil microbial community in areas they invade, therefore making it easier for invasive plant species to establish themselves over native species (Callaway et al. 2004; Yu et al. 2005). At the same time, such changes in microbial community composition can be reversible (Dickens et al. 2013). This opens up the possibility that restoration of the native microbial community might result in conditions favorable to native plants (De Deyn et al. 2003). Thus, soil from native-dominated communities might help reestablish native soil microbial communities to increase native plant growth (Rowe et al. 2009).

Historically, the ability of microbes to influence seed dormancy has not been well supported by data (Baskin and Baskin 2000), although many crop studies indicate that so-called plant growth-promoting bacteria can increase seed germination (Lucy et al. 2004; Wu et al. 2016). Many soil microbes are either pathogenic to seeds or they may protect seeds from pathogens. Microbes that provide protection from pathogens may be especially important to plant species whose seeds remain in the soil for long periods of time prior to germinating (Dalling et al. 2011). One group of bacteria that can influence germination timing are the pinkpigmented facultative methylotrophs (PPFMs), within the genus Methylobacterium (Madhaiyan et al. 2005). PPFMs are widespread bacteria associated with the roots, leaves, and seeds of most 
terrestrial plants, but also found in air, water, and soil. Although they have been shown to increase germination and seedling growth of a native coastal sage scrub species, Artemisia californica, but not for a common invasive species, Brassica nigra (Irvine et al. 2013), the group is not commonly used in restoration. Thus, having a better understanding of the influence of microbes and PPFMs on seed germination may help practitioners increase the success and costeffectiveness of future restoration efforts.

The purchase of native seeds and plants can be one of the significant costs of restoration projects (Kimball et al. 2015). Information regarding the germination biology of native species used in restoration allows practitioners to refine seeding methods in the field and increases the success of plant propagation in containers or in native seed farms (Broadhurst et al. 2016; Limon and Peco 2016). Knowledge regarding the timing of germination for native species compared to invasive species may help clarify the outcome of competitive interactions (Forbis 2010; Wainwright and Cleland 2013) and may help land managers with the timing of herbicide application and weeding in restoration (Marushia et al. 2010). For instance, land managers might use specialized herbicides during times when only certain functional groups have emerged or to allow crews to weed early-germinating non-native species prior to native species emergence, both of which would reduce costs associated with educating field crews on native and non-native species identification.

Here, we investigate the timing of germination, the percent germination of native and invasive species, and the role of soil microorganisms, providing information to assist in the successful re-establishment of native species. We selected a majority of the native species typically seeded in restoration of Southern California coastal sage scrub and prairie (aka "grassland") plant communities as well as four globally problematic invasive species and 
measured germination under different controlled environments: sterile, inoculated with a slurry from field-collected soil, and inoculated with lab-grown PPFM that was isolated from fieldcollected soil. For three plant species that are known to require liquid smoke or gibberellic acid to break endogenous dormancy, we added a chemically manipulated dormancy-breaking treatment to better understand these specific cases. Our research objectives were to determine whether the number of days required for seed germination to occur and the percent germination (total number of seeds that germinate/total number of seeds) varied depending on the species, the inoculation treatment, or an interaction between the two factors. We also asked whether plant responses varied depending on key plant characteristics, including seed weight, functional group (grass, shrub, or forb), or provenance (native to California or non-native). We tested three hypotheses: (1) Non-native grasses and forbs would germinate earlier and at higher percentages than native grasses, shrubs, and forbs; (2) Native species would have faster germination timing and increased percent germination when treated with inoculum from native-dominated coastal sage scrub soil; and (3) PPFM inoculation would hasten germination timing and increase percent germination of native species, but not of invasive species. Results from this study will inform restoration practices by influencing decisions on timing and methods of seeding and herbicide application. Additionally, results will determine the effectiveness of using microbial inocula to influence germination timing and success.

\section{Materials and methods}

Species commonly found in Southern California coastal sage scrub and prairie plant communities were used for this experiment (Table 1). Nineteen species in total were used, 
including fifteen native and four non-natives. The seeds for each native species were sourced from S\&S Seeds, which is a commonly used seed source for restoration projects in Orange County, CA. Seeds of non-native species were collected from the field (Table 1). All of the seeds were cleaned by removing excess litter, awns, husks, or other appendages, which also acted to remove known physical dormancy breaking barriers for several species (Table 1). We used an estimate of the percent germination of each species (from external sources or from our own work, Table S1) to inform the number of seeds included in each petri dish, with a target of ten seeds capable of emerging per replicate. For species that we did not have experience with, we ran preliminary germination trials to estimate percent germination. For species with very small seeds, we used data on seed mass to determine sample weights required to place in petri dishes to achieve the desired number of seedlings. For all species, there were seven replicate petri dishes for each of the three treatments (sterile, soil inoculum, and PPFM). Three species, (Eschscholzia californica, Penstemon spectabilis, and Phacelia cicutaria), included an additional treatment to evaluate our experimental manipulations in the context of known chemical dormancy breaking requirements such as soaking in gibberellic acid or liquid smoke (Table 1).

On the day that the experiment was initiated, all of the seeds were sterilized in a bleach solution for two minutes. Seeds were then placed into petri dishes lined with a single Whatman $70 \mathrm{~mm}$ filter paper, sprayed for five seconds with the given inoculant $(<0.1 \mathrm{ml})$, and placed on sterilized trays, stacked in layers of two. Petri dishes were randomly assigned to one of two identical growth chambers, each set to $65 \%$ relative humidity, $400 \mathrm{ppm} \mathrm{CO}_{2}$, and a daytime temperature of $20^{\circ} \mathrm{C}\left(68^{\circ} \mathrm{F}\right)$ and a nighttime temperature of $8^{\circ} \mathrm{C}\left(46^{\circ} \mathrm{F}\right)$ on a 12 hours day/night (light/dark) cycle. For each species-treatment combination, we placed three of the seven 
replicates in one given chamber and four in the other to account for differences amongst chambers.

The soil inoculant was created by collecting the top $2 \mathrm{~cm}$ of soil from an area in healthy native coastal sage scrub community, adjacent to the West Loma Ecological Restoration Experiment in Orange County, CA (Kimball et al. 2015). The soil was sifted multiple times until only a fine, smooth dust remained. This fine dust was then mixed with a sterile $0.9 \%$ saline solution to create a slurry. The slurry was then filtered through several size filters: $100 \mu \mathrm{m}$, $25 \mu \mathrm{m}$ and $5 \mu \mathrm{m}$, and transferred to a spray bottle for inoculating petri dishes.

We isolated PPFMs using the same soil that was used to create soil slurry. A dilution series was created in NMS (nitrate mineral salts) media and plated on NMS agar plates with cyclohexamide and incubated at $30^{\circ} \mathrm{C}$. After five days, pink colonies were streaked on new plates and incubated at room temperature, and this procedure was repeated again with a regrown colony. A single colony was then picked and grown in a liquid NMS media to use as the PPFM inoculum. This isolate was $\geq 99.9 \%$ similar in its partial $16 \mathrm{~S}$ sequence ( $838 \mathrm{bp}$; Genbank accession KX825863) to Methylobacterium extorquens strain 5-3-1.1(2). Sterile liquid NMS media was used as the control treatment.

After initiating the experiment, each petri dish was monitored daily for germination and was watered with sterilized DI water if the filter paper appeared dry. The dishes and trays were rotated daily to account for spatial variation within the growth chamber itself. We recorded the date that each seed germinated, defined as when the radical first emerged from the seed coat. Any visible fungal growth was also recorded.

We used mixed model ANOVAs to determine whether the time required for germination (the number of days between initiating the experiment and radical emergence), and whether the 
percent germination varied depending on species, treatment (control, soil, or PPFM), or the interaction between the two factors. Petri dish and growth chamber were included as random factors in the analyses. Species with fewer than five individuals germinating in each treatment group (Baccharis emoryi, Penstemon spectabilis, and Phacelia cicutaria) were excluded from the multi-species analysis of germination timing, leaving a total of 16 species. We used Tukey post-hoc tests to determine significant differences amongst species and treatment groups. Species in which fewer than five petri dishes had germinating seeds in any treatment were excluded from Tukey post-hoc tests on percent germination. We also ran separate analyses on germination timing and percent germination for each species, including those that had a fourth, dormancy-breaking treatment (Eschscholzia californica, Penstemon spectabilis, and Phacelia cicutaria) to determine the influence of germination treatment, including the chemical treatment, on timing of germination and on percent germination within each of those species, including dish and chamber as random factors.

We used ANCOVA to determine whether differences in germination timing amongst species were due to differences in seed weight, percent germination, or inoculation treatment $\left(\right.$ model MGT $=$ MPG + MSW + Treatment $+\mathrm{MPG}^{*}$ Treatment + MSW*Treatment, where MGT $=$ mean germination time, $\mathrm{MSW}=$ mean seed weight, $\mathrm{MPG}=$ mean percent germination, and treatment=soil, PPFM, or control). We calculated Pearson Correlation Coefficients for mean seed weight, mean percent germination, and mean germination time to identify any relationships amongst these continuous variables. We also used general linear models to investigate whether MGT, MPG, or MSW varied depending on the functional group of the species or the provenance of the species. Finally, to understand whether inoculants influenced the presence of fungal pathogens, we used a generalized linear model (Proc GENMOD in SAS with a logit link) to 
determine whether the probability that a petri dish contained mold was related to the species or the inoculation treatment.

\section{Results}

Germination timing and percentage varied significantly depending on the inoculation treatment, but the direction of the effect varied depending on the species (Figures 1 and 2, Tables 2 and 3). Almost all species took longer to germinate when treated with the soil microbial inoculum than in the control or PPFM treatments (Fig. 1, Table S2). The native shrub, Rhus integrifolia, took the longest time to germinate, in all three treatments (Fig. 1, Table S2). Seeds of Brassica nigra and Erodium cicutarium, both invasive forb species, germinated fastest in the control group, followed by Lupinus succulentus and Lupinus bicolor, both native forbs. For two native forbs, Phacelia cicutaria and Penstemon spectabilis, less than five seeds germinated in control, soil, and PPFM treatments, so only values from the chemical treatment were used to graph germination timing (Fig. 1). Several native species (Lupinus succulentus, Amsinckia menziesii, Encelia californica, Elymus condensatus, and Eriogonum fasciculatum) tended to germinate fastest in the PPFM treatment, but this was also true for the invasive grass, Bromus diandrus (Fig. 1).

The four invasive species that were studied exhibited the highest overall percent germination (Fig. 2, Tables 3, 4, and S3). Seeds in the soil inoculation treatment had significantly lower percent germination than in control and PPFM treatments for most species (Table S3). For example, the invasive species, Brassica nigra and Bromus diandrus, and the native Amsinckia menziesii experienced $20 \%$ lower germination with the soil slurry inoculant 
than it did with the control (Fig. 2). Most species germinated at higher percentages in the PPFM treatment (Fig. 2). The native shrub, Encelia californica, had significantly higher percent germination when treated with PPFM, but so did the non-native, invasive grass, Bromus diandrus (Fig. 2, Table 2). One species, Baccharis emoryi, had very low percent germination in all treatments (Fig. 2).

Of the three native species for which we included a chemical treatment (liquid smoke for Eschscholzia californica and Phacelia cicutaria, and GA for Penstemon spectabilis), the chemical treatment resulted in slower germination for Eschscholzia californica than in control or PPFM groups (Fig. 1, Table 2). Chemical treatment improved percent germination for Phacelia cicutaria and Penstemon spectabilis (Fig. 2, Table 3). In fact, these two species had such low percentages in other treatments that they were excluded from the across species analyses.

The native shrubs had significantly lower percent germination than other functional groups (Fig. 2, Tables 3, 4, and S3). Species that germinated fast also had high percent germination and low seed mass (Table 4 and S4). Non-native species germinated significantly faster and at significantly higher percentages than native species (although a few native forbs germinated quickly as well). Shrubs took significantly longer to germinate than grasses and forbs (Table 4). Contrary to our hypotheses, the effect of inoculum treatment was not significantly related to provenance or functional group (Table 4).

Visible fungal growth was significantly greater in the soil treatment than in the PPFM or control treatments (treatment $\mathrm{X}^{2}=12.7, P=0.0017$ ). This growth was also significantly greater in the petri dishes with species that took longer to germinate (species $\left.X^{2}=102.7, P<0.0001\right)$.

\section{Discussion}


Using the most common species from California coastal sage scrub and prairie plant communities, we found that microbial inoculation treatments altered germination timing by up to 7 days and altered percent germination by up to $20 \%$ compared to controls, but that the direction of the effect varied depending on species. Although each species responded differently, soil inoculum tended to increase the number of days required for germination and to lower overall percent germination, while PPFM tended in increase percent germination relative to the controls. Surprisingly, the effect of inoculants did not vary consistently based on the functional group or whether the species was native to California. Interactions between plants and microbes can be beneficial or negative to the species involved (Reynolds et al. 2003). In one restoration study, the use of commercial arbuscular mycorrhizal inoculum reduced the growth of native coastal sage scrub plants, suggesting a negative effect of fungi on plants (Aprahamian et al. 2016). In the present study, the role of native soil inoculum was consistently negative, resulting in slower germination timing and lower germination percentages, suggesting that pathogenic organisms in the soil may have negatively influenced both native and invasive plant species. Indeed, we observed greater fungal growth on petri dishes with the soil inoculum treatment. Species that took longer to germinate, such as the native shrub species, were especially negatively influenced by fungal growth in petri dishes that had the soil inoculum treatment.

PPFM has been shown to influence plant growth hormones and pathogen resistance (Madhaiyan et al. 2004; Savitha et al. 2013). We do not know the exact mechanism by which PPFMs increased the speed and percentage of germination for some of the species in our study. For two of the three species that are known to require some type of chemical treatment to break seed dormancy, the chemical treatment was superior to PPFM, while for Eschscholtzia 
californica, PPFM was slightly more effective than liquid smoke in breaking dormancy.

Additional work would be necessary to clarify PPFM utility in restoration settings, and could be complimented by mechanistic studies evaluating the specific action caused by the symbiont.

The functional group, provenance, and seed weight significantly influenced germination timing and percentages. Similar to results from previous studies (Vaughn and Young 2015; Wainwright and Cleland 2013; Wainwright et al. 2012), the non-native, invasive species in our study tended to have smaller seeds and germinate faster than the natives. The exception to this was some of the native forbs with large seeds that germinated faster than the invasive grass species. The ability of non-native species to rapidly germinate and establish prior to native species provides them with a competitive advantage from the earliest stages of plant growth (Wainwright and Cleland 2013). This may be especially true in recently disturbed environments or in restoration settings where native shrubs, which were the slowest to germinate in our study, must compete with invasive species as seedling when they are in the similar plant-size classes. Restoration practitioners could use this information to control non-native species after the first winter rains promote non-native germination and before native species emergence (Marushia et al. 2010). Since grasses and forbs germinated significantly earlier than shrubs, practitioners could potentially expand the window between non-native and native germination by seeding only native shrubs during preliminary restoration efforts at a site. This approach would allow for more time to treat non-native species prior to native germination, promote grow-kill cycles that reduce non-native densities, and benefit restoration success by reducing competition amongst natives of different functional groups (Kimball et al. 2014), although restoring a diversity of native functional groups is important for achieving a fully-functioning community (Mischkolz et al. 2016; Polley et al. 2005). 
The invasive species also germinated at significantly higher percentages than the native species, consistent with other studies comparing percent germination of native and invasive species (Beckmann et al. 2011; Colautti et al. 2006; Wainwright and Cleland 2013). The nonnatives in our study had percent germination that were all around $70 \%$ or higher, while the percent germination of natives ranged from $0 \%$ in some treatments up to almost $70 \%$. The lower percent germination of natives may be a result of prolonged dormancy, a bet hedging strategy that increases long-term fitness in variable environments such as our study system (Venable 2007). In contrast, invasive species seem to lack dormancy that requires specific environmental cues to trigger germination (Wainwright and Cleland 2013). One exception to this is Erodium cicutarium, a non-native that required seed scarification to break exogenous dormancy prior to germination.

Soil slurry consistently decreased the fraction of seeds germinating within a cohort of seeds and increased the time-to-germination of seeds actually germinating as compared to both PPFM (isolated from the soil) and control, suggesting that organisms or compounds in this solution restricted germination. The fact that soil slurry had a more negative impact than organisms previously identified as promoting germination (isolated PPFM) is not unanticipated because soil slurry might also contain organisms that act as pathogens or small amounts of allelopathic chemicals that could inhibit germination. Conditions specific to petri dishes may have also favored the spread of pathogenic microbes. This suggests that more mechanistic study of the impacts of PPFM on germination would be warranted to understand such issues as if pretreatment with PPFM would promote germination followed by subsequent exposure to soil microorganisms (as would happen in restoration projects). In addition, the use of either chemical products (e.g., cyclohexamide) or biological control over fungal species that may have caused 
the negative effects in this study could be of practical and scientific benefit. For example, it would be interesting to include cyclohexamide with the soil slurry to suppress fungal growth and evaluate the independent effect of the bacterial community on germination in future trials.

In conclusion, we found that forbs and grasses, especially non-native ones, germinated faster than shrubs. The invasive species in our study germinated at significantly higher percentages than native species. Species with larger seeds took longer to germinate and germinated at lower percentages than species with smaller seeds. PPFM may increase percent germination of some native and non-native species, while the addition of soil inoculum decreased the timing and percentages of germination for all species. Our results point to the effectiveness of using herbicide or hand-weeding to remove non-native species after germination-triggering rain events, but prior to the germination of native species, as long as native forbs are not included in the native seed palette.

\section{Acknowledgements}

Thanks to the California Coastal Commission's Community-based restoration project and to Dr. Paula Schiffman for providing the seeds for this study. We thank the undergraduate student interns from University of California, Irvine's Center for Environmental Biology for assisting with data collection. Funding was provided by the Center for Environmental Biology, which receives support from the Voth Family Trust, The Nature Conservancy, and the Natural Communities Coalition. 


\section{References}

Allen, E.B., Allen, M.E., Egerton-Warburton, L., Corkidi, L., and Gomez-Pompa, A. 2003. Impacts of early- and late-seral mycorrhizae during restoration in seasonal tropical forest, Mexico. Ecol. Applications 13(6): 1701-1717. doi: 10.1890/02-5309.

Aprahamian, A.M., Lulow, M.E., Major, M.R., Balazs, K.R., Treseder, K.K., and Maltz, M.R. 2016. Arbuscular mycorrhizal inoculation in coastal sage scrub restoration. Botany 94(6): 493-499. doi: 10.1139/cjb-2015-0226.

Baskin, J.M., and Baskin, C.C. 2000. Evolutionary considerations of claims for physical dormancy-break by microbial action and abrasion by soil particles. Seed Sci. Res. 10(4): 409-413.

Beckmann, M., Bruelheide, H., and Erfmeier, A. 2011. Germination responses of three grassland species differ between native and invasive origins. Ecol. Res. 26(4): 763-771. doi: 10.1007/s11284-011-0834-3.

Broadhurst, L.M., Jones, T.A., Smith, F.S., North, T., and Guja, L. 2016. Maximizing Seed Resources for Restoration in an Uncertain Future. Bioscience 66(1): 73-79. doi: 10.1093/biosci/biv155.

Callaway, R.M., Thelen, G.C., Rodriguez, A., and Holben, W.E. 2004. Soil biota and exotic plant invasion. Nature 427(6976): 731-733. doi: 10.1038/nature02322.

Colautti, R.I., Grigorovich, I.A., and MacIsaac, H.J. 2006. Propagule pressure: A null model for biological invasions. Biol. Invasions 8(5): 1023-1037. doi: 10.1007/s10530-005-3735-y.

Dalling, J.W., Davis, A.S., Schutte, B.J., and Arnold, A.E. 2011. Seed survival in soil: interacting effects of predation, dormancy and the soil microbial community. J. Ecol. 99(1): 89-95. doi: 10.1111/j.1365-2745.2010.01739.x.

De Deyn, G.B., Raaijmakers, C.E., Zoomer, H.R., Berg, M.P., de Ruiter, P.C., Verhoef, H.A., Bezemer, T.M., and van der Putten, W.H. 2003. Soil invertebrate fauna enhances grassland succession and diversity. Nature 422(6933): 711-713. doi: 10.1038/nature01548.

Dickens, S.J.M., Allen, E.B., Santiago, L.S., and Crowley, D. 2013. Exotic annuals reduce soil heterogeneity in coastal sage scrub soil chemical and biological characteristics. Soil Biology \& Biochemistry 58: 70-81. doi: 10.1016/j.soilbio.2012.09.028.

Forbis, T.A. 2010. Germination phenology of some Great Basin native annual forb species. Plant Spec. Biol. 25(3): 221-230. doi: 10.1111/j.1442-1984.2010.00289.x.

Guthrie, S.G., Crandall, R.M., and Knight, T.M. 2016. Fire indirectly benefits fitness in two invasive species. Biol. Invasions 18(5): 1265-1273. doi: 10.1007/s10530-016-1064-y.

Irvine, I.C., Witter, M.S., Brigham, C.A., and Martiny, J.B.H. 2013. Relationships between Methylobacteria and Glyphosate with Native and Invasive Plant Species: Implications for Restoration. Restor. Ecol. 21(1): 105-113. doi: 10.1111/j.1526-100X.2011.00850.x.

Jimenez-Alfaro, B., Silveira, F.A.O., Fidelis, A., Poschlod, P., and Commander, L.E. 2016. Seed germination traits can contribute better to plant community ecology. J. Veg. Sci. 27(3): 637-645. doi: 10.1111/jvs.12375.

Kimball, S., Lulow, M., Sorenson, Q., Balazs, K., Fang, Y.-C., Davis, S.J., O'Connell, M., and Huxman, T.E. 2015. Cost-effective ecological restoration. Restoration Ecology 23(6): 800-810. doi: 10.1111/rec.12261. 
Kimball, S., Lulow, M.E., Mooney, K.A., and Sorenson, Q.M. 2014. Establishment and management of native functional groups in restoration. Restoration Ecology 22(1): 81-88.

Kourtev, P.S., Ehrenfeld, J.G., and Haggblom, M. 2003. Experimental analysis of the effect of exotic and native plant species on the structure and function of soil microbial communities. Soil Biology \& Biochemistry 35(7): 895-905. doi: 10.1016/s00380717(03)00120-2.

Kulmatiski, A., Beard, K.H., and Stark, J.M. 2006. Soil history as a primary control on plant invasion in abandoned agricultural fields. J of Appl. Ecology 43(5): 868-876. doi: 10.1111/j.1365-2664.2006.01192.x.

Limon, A., and Peco, B. 2016. Germination and emergence of annual species and burial depth: Implications for restoration ecology. Acta Oecol.-Int. J. Ecol. 71: 8-13. doi: 10.1016/j.actao.2016.01.001.

Lucy, M., Reed, E., and Glick, B.R. 2004. Applications of free living plant growth-promoting rhizobacteria. Antonie Van Leeuwenhoek 86(1): 1-25. doi: 10.1023/B:ANTO.0000024903.10757.6e.

Madhaiyan, M., Poonguzhali, S., Lee, H.S., Hari, K., Sundaram, S.P., and Sa, T.M. 2005. Pinkpigmented facultative methylotrophic bacteria accelerate germination, growth and yield of sugarcane clone Co86032 (Saccharum officinarum L.). Biol. Fertil. Soils 41(5): 350358. doi: 10.1007/s00374-005-0838-7.

Madhaiyan, M., Poonguzhali, S., Senthilkumar, M., Seshadri, S., Chung, H.Y., Yang, J.C., Sundaram, S., and Sa, T.M. 2004. Growth promotion and induction of systemic resistance in rice cultivar Co-47 (Oryza sativa L.) by Methylobacterium spp. Botanical Bulletin of Academia Sinica 45(4): 315-324.

Maltz, M.R., and Treseder, K.K. 2015. Sources of inocula influence mycorrhizal colonization of plants in restoration projects: a meta-analysis. Restoration Ecology 23(5): 625-634. doi: 10.1111/rec.12231.

Marushia, R.G., Cadotte, M.W., and Holt, J.S. 2010. Phenology as a basis for management of exotic annual plants in desert invasions. J of Appl. Ecology 47(6): 1290-1299. doi: 10.1111/j.1365-2664.2010.01881.x.

Mischkolz, J.M., Schellenberg, M.P., and Lamb, E.G. 2016. Assembling productive communities of native grass and legume species: finding the right mix. Appl. Veg. Sci. 19(1): 111-121. doi: 10.1111/avsc.12200.

Mordecai, E.A. 2012. Soil Moisture and Fungi Affect Seed Survival in California Grassland Annual Plants. PLoS One 7(6): 8. doi: 10.1371/journal.pone.0039083.

Perez-Fernandez, M.A., Calvo-Magro, E., and Valentine, A. 2016. Benefits of the Symbiotic Association of Shrubby Legumes for the Rehabilitation of Degraded Soils under Mediterranean Climatic Conditions. Land Degrad. Dev. 27(2): 395-405. doi: 10.1002/ldr.2457.

Polley, H.W., Derner, J.D., and Wilsey, B.J. 2005. Patterns of plant species diversity in remnant and restored tallgrass prairies. Restoration Ecology 13(3): 480-487. doi: 10.1111/j.1526100X.2005.00060.x.

Requena, N., Perez-Solis, E., Azcon-Aguilar, C., Jeffries, P., and Barea, J.M. 2001. Management of indigenous plant-microbe symbioses aids restoration of desertified ecosystems. Appl. Environ. Microbiol. 67(2): 495-498. doi: 10.1128/aem.67.2.495-498.2001. 
Reynolds, H.L., Packer, A., Bever, J.D., and Clay, K. 2003. Grassroots ecology: Plant-microbesoil interactions as drivers of plant community structure and dynamics. Ecology 84(9): 2281-2291. doi: 10.1890/02-0298.

Rowe, H.I., Brown, C.S., and Paschke, M.W. 2009. The Influence of Soil Inoculum and Nitrogen Availability on Restoration of High-Elevation Steppe Communities Invaded by Bromus tectorum. Restoration Ecology 17(5): 686-694. doi: 10.1111/j.1526-100X.2008.00385.x.

Savitha, P., Sreenivasa, M.N., and Nirmalnath, J.P. 2013. Production of Plant Growth Hormones by Pink Pigmented Facultative Methylotrophs. J. Pure Appl. Microbiol. 7(2): 981-985.

SER. 2004. The SER International Primer on Ecological Restoration. Society for Ecological Restoration International.

Thrall, P.H., Millsom, D.A., Jeavons, A.C., Waayers, M., Harvey, G.R., Bagnall, D.J., and Brockwell, J. 2005. Seed inoculation with effective root-nodule bacteria enhances revegetation success. J of Appl. Ecology 42(4): 740-751. doi: 10.1111/j.13652664.2005.01058.x.

Vaughn, K.J., and Young, T.P. 2015. Short-term priority over exotic annuals increases the initial density and longer-term cover of native perennial grasses. Ecol. Applications 25(3): 791 799. doi: 10.1890/14-0922.1.sm.

Venable, D.L. 2007. Bet hedging in a guild of desert annuals. Ecology 88(5): 1086-1090. doi: 10.1890/06-1495.

Wainwright, C.E., and Cleland, E.E. 2013. Exotic species display greater germination plasticity and higher germination rates than native species across multiple cues. Biol. Invasions 15(10): 2253-2264. doi: 10.1007/s10530-013-0449-4.

Wainwright, C.E., Wolkovich, E.M., and Cleland, E.E. 2012. Seasonal priority effects: implications for invasion and restoration in a semi-arid system. J of Appl. Ecology 49(1): 234-241. doi: 10.1111/j.1365-2664.2011.02088.x.

Wu, Y.N., Feng, Y.L., Pare, P.W., Chen, Y.L., Xu, R., Wu, S., Wang, S.M., Zhao, Q., Li, H.R., Wang, Y.Q., and Zhang, J.L. 2016. Beneficial soil microbe promotes seed germination, plant growth and photosynthesis in herbal crop Codonopsis pilosula. Crop Pasture Sci. 67(1): 91-98. doi: 10.1071/cp15110.

Yu, X.J., Yu, D., Lu, Z.J., and Ma, K.P. 2005. A new mechanism of invader success: Exotic plant inhibits natural vegetation restoration by changing soil microbe community. Chinese Science Bulletin 50(11): 1105-1112. doi: 10.1360/04wc0280.

Yurkonis, K.A., Wilsey, B.J., Moloney, K.A., and van der Valk, A.G. 2008. The Impact of Seeding Method on Diversity and Plant Distribution in Two Restored Grasslands. Restoration Ecology 18(3): 311-321. doi: 10.1111/j.1526-100X.2008.00461.x. 


\section{Tables}

Table 1: The list of species included in our study, whether or not they are native, the functional group to which they belong, their lifespan, average seed weight, collection data, and additional dormancy-breaking mechanisms used in our experiment, and estimated \% germination used to determine sample sizes.

\begin{tabular}{|c|c|c|c|c|c|c|c|}
\hline Species Name & Native & $\begin{array}{l}\text { Function } \\
\text { Group }\end{array}$ & Lifespan & Weight (g) & $\begin{array}{c}\text { Collection } \\
\text { data }\end{array}$ & $\begin{array}{l}\text { Dormancy- } \\
\text { breaking } \\
\text { Mechanism }\end{array}$ & $\begin{array}{l}\text { Estimated \% } \\
\text { Germination }\end{array}$ \\
\hline $\begin{array}{c}\text { Amsinckia } \\
\text { menziesii }\end{array}$ & Yes & Forb & Annual & 0.0022 & $\begin{array}{l}\text { S\&S Seeds } \\
\text { \#OP-55634 }\end{array}$ & - & 40 \\
\hline $\begin{array}{c}\text { Atriplex } \\
\text { lentiformis }\end{array}$ & Yes & Shrub & Perennial & 0.000940 & $\begin{array}{l}\text { S\&S Seeds } \\
\text { \#OP-55634 }\end{array}$ & - & 10 \\
\hline Brassica nigra & No & Forb & Annual & 0.001355 & $\begin{array}{l}\text { Spring 2015, } \\
\text { Orange Co. }\end{array}$ & - & 80 \\
\hline $\begin{array}{l}\text { Bromus } \\
\text { diandrus }\end{array}$ & No & Grass & Annual & 0.00788 & $\begin{array}{l}\text { Spring } 2015 \text {, } \\
\text { Orange Co. }\end{array}$ & - & 80 \\
\hline $\begin{array}{c}\text { Bromus } \\
\text { madritensis }\end{array}$ & No & Grass & Annual & 0.001175 & $\begin{array}{l}\text { Spring 2015, } \\
\text { Orange Co. }\end{array}$ & - & 80 \\
\hline $\begin{array}{c}\text { Elymus } \\
\text { condensatus }\end{array}$ & Yes & Grass & Perennial & 0.001730 & $\begin{array}{l}\text { S\&S Seeds } \\
\text { \#OP-55634 }\end{array}$ & - & 50 \\
\hline $\begin{array}{c}\text { Encelia } \\
\text { californica }\end{array}$ & Yes & Shrub & Perennial & 0.001485 & $\begin{array}{l}\text { S\&S Seeds } \\
\text { \#OP-55634 }\end{array}$ & - & 30 \\
\hline $\begin{array}{l}\text { Eriogonum } \\
\text { fasciculatum }\end{array}$ & Yes & Shrub & Perennial & 0.0003695 & $\begin{array}{l}\text { S\&S Seeds } \\
\text { \#OP-55634 }\end{array}$ & - & 50 \\
\hline Erodium & No & Forb & Annual & 0.0013052 & March 11, & physical & 50 \\
\hline
\end{tabular}




\begin{tabular}{|c|c|c|c|c|c|c|c|}
\hline cicutarium & & & & 6 & $\begin{array}{l}201034.298 \\
\mathrm{~N}, 118.531 \mathrm{~W}\end{array}$ & scarification & \\
\hline $\begin{array}{l}\text { Eschscholzia } \\
\text { californica }\end{array}$ & Yes & Forb & $\begin{array}{l}\text { Annual, } \\
\text { Perennial }\end{array}$ & 0.001890 & $\begin{array}{l}\text { S\&S Seeds } \\
\text { \#OP-55634 }\end{array}$ & smoke & 40 \\
\hline $\begin{array}{l}\text { Lupinus } \\
\text { bicolor }\end{array}$ & Yes & Forb & $\begin{array}{l}\text { Annual, } \\
\text { Perennial }\end{array}$ & 0.004680 & $\begin{array}{l}\text { S\&S Seeds } \\
\text { \#OP-55634 }\end{array}$ & hot water & 40 \\
\hline $\begin{array}{c}\text { Lupinus } \\
\text { succulentus }\end{array}$ & Yes & Forb & Annual & 0.02623 & $\begin{array}{l}\text { S\&S Seeds } \\
\text { \#OP-55634 }\end{array}$ & hot water & 40 \\
\hline $\begin{array}{l}\text { Malosma } \\
\text { laurina }\end{array}$ & Yes & Shrub & Perennial & 0.003379 & $\begin{array}{l}\text { S\&S Seeds } \\
\text { \#OP-55634 }\end{array}$ & $\begin{array}{c}\text { cold } \\
\text { stratification }\end{array}$ & 50 \\
\hline $\begin{array}{l}\text { Penstemon } \\
\text { spectabilis }\end{array}$ & Yes & Forb & Perennial & 0.007590 & $\begin{array}{l}\text { S\&S Seeds } \\
\text { \#OP-55634 }\end{array}$ & $\begin{array}{c}\text { GA soak: } 24 \\
\text { hrs. in } \\
\text { 750ppm } \\
\text { solution }\end{array}$ & 20 \\
\hline $\begin{array}{l}\text { Peritoma } \\
\text { arborea }\end{array}$ & Yes & Shrub & Perennial & 0.125050 & $\begin{array}{l}\text { S\&S Seeds } \\
\text { \#OP-55634 }\end{array}$ & - & 20 \\
\hline $\begin{array}{l}\text { Phacelia } \\
\text { cicutaria }\end{array}$ & Yes & Forb & Annual & 0.000820 & $\begin{array}{l}\text { S\&S Seeds } \\
\text { \#OP-55634 }\end{array}$ & smoke & 20 \\
\hline $\begin{array}{c}\text { Rhus } \\
\text { integrifolia }\end{array}$ & Yes & Shrub & Perennial & 0.061250 & $\begin{array}{l}\text { S\&S Seeds } \\
\text { \#OP-55634 }\end{array}$ & $\begin{array}{c}\text { physical } \\
\text { scarification } \\
\text { and soaking } \\
\text { for } 4 \text { days }\end{array}$ & 50 \\
\hline Stipa pulchra & Yes & Grass & Perennial & 0.003795 & $\begin{array}{l}\text { S\&S Seeds } \\
\text { \#OP-55634 }\end{array}$ & - & 30 \\
\hline
\end{tabular}


Table 2. Results from ANOVAs with germination timing (the number of days between the initiation of the experiment and germination) as the dependent variable. Results from Tukey post-hoc tests are provide in Table S2.

\begin{tabular}{|c|c|c|c|c|c|}
\hline \multicolumn{6}{|c|}{$\begin{array}{l}\text { A. Results from a mixed-model ANOVA on the effect of treatment and } \\
\text { species on the number of days between saturation and germination }\end{array}$} \\
\hline Effect & NumDF & DenomDF & $\mathbf{F}$ & $\mathbf{P}$ & \\
\hline Species & 15 & 3102 & 176.63 & $<.0001$ & \\
\hline Treatment & 2 & 3102 & 23.04 & $<.0001$ & \\
\hline Species*Treatment & 30 & 3102 & 2.43 & $<.0001$ & \\
\hline
\end{tabular}

B. Results from mixed-model ANOVAS on the effect of treatment on germination timing of each species.

\begin{tabular}{|l|l|r|r|r|l|}
\hline Species & & & Denom & & \\
\hline Amsinckia menziesii & Treatment & 2 & 232 & 3.26 & 0.0403 \\
\hline Atriplex lentiformis & Treatment & 2 & 402 & 26.43 & $<.0001$ \\
\hline Brassica nigra & Treatment & 2 & 271 & 47.73 & $<.0001$ \\
\hline Bromus diandrus & Treatment & 2 & 237 & 1.49 & 0.2285 \\
\hline Bromus madritensis & Treatment & 2 & 210 & 0.83 & 0.4375 \\
\hline Elymus condensatus & Treatment & 2 & 161 & 1.48 & 0.2306 \\
\hline Encelia californica & Treatment & 2 & 104 & 1.51 & 0.2257 \\
\hline Eriogonum & & & & & \\
fasciculatum & Treatment & 2 & 55 & 0.64 & 0.53 \\
\hline
\end{tabular}




\begin{tabular}{|c|c|c|c|c|c|}
\hline Erodium cicutarium & Treatment & 2 & 364 & 9.69 & $<.0001$ \\
\hline Eschscholzia & & & & & \\
\hline californica & Treatment & 3 & 133 & 10.08 & $<.0001$ \\
\hline Lupinus bicolor & Treatment & 2 & 156 & 1.76 & 0.1747 \\
\hline Lupinus succulentus & Treatment & 2 & 295 & 0.8 & 0.4516 \\
\hline Malosma laurina & Treatment & 2 & 53 & 0.19 & 0.8295 \\
\hline Penstemon spectabilis & Treatment & 2 & 150 & 2.85 & 0.0611 \\
\hline Peritoma arborea & Treatment & 2 & 54 & 4.41 & 0.0168 \\
\hline Phacelia cicutaria & Treatment & 3 & 9 & 2.45 & 0.1307 \\
\hline Rhus integrifolia & Treatment & 2 & 20 & 0.41 & 0.6668 \\
\hline Stipa pulchra & Treatment & 2 & 266 & 0.61 & 0.5449 \\
\hline
\end{tabular}


Table 3. Results from mixed model ANOVAs with percent germination (the number of seeds that germinated per petri dish divided by the total number of seeds in each dish) as the dependent variable and growth chamber as a random variable. Results from Tukey post-hoc tests are provided in Table S3.

\begin{tabular}{|c|c|c|c|c|c|}
\hline \multicolumn{6}{|c|}{$\begin{array}{l}\text { A. Results from ANOVA including data from the three inoculation } \\
\text { treatments that were applied to all species (control, soil, and PPFM). }\end{array}$} \\
\hline Effect & NumDF & DenomDF & $\mathbf{F}$ & $\mathbf{P}$ & \\
\hline Species & 15 & 286 & 130.69 & $<.0001$ & \\
\hline Treatment & 2 & 286 & 21.94 & $<.0001$ & \\
\hline Species*Treatment & 30 & 286 & 2.07 & 0.0012 & \\
\hline \multicolumn{6}{|c|}{$\begin{array}{l}\text { B. Results from separate ANOVAs for each species. For three of the } \\
\text { species this included a fourth treatment (smoke for ESCCAL and PHACIC } \\
\text { and GA for PENSPE). }\end{array}$} \\
\hline Species & Effect & Num DF & $\begin{array}{l}\text { Denom } \\
\text { DF }\end{array}$ & $\mathbf{F}$ & $\mathbf{P}$ \\
\hline Amsinckia menziesii & Treatment & 2 & 17 & 12.71 & 0.0004 \\
\hline Atriplex lentiformis & Treatment & 2 & 17 & 0.25 & 0.7852 \\
\hline Baccharis emoryi & Treatment & 2 & 17 & 1.02 & 0.3816 \\
\hline Brassica nigra & Treatment & 2 & 17 & 18.06 & $<.0001$ \\
\hline Bromus diandrus & Treatment & 2 & 17 & 4.57 & 0.0258 \\
\hline Bromus madritensis & Treatment & 2 & 17 & 0.07 & 0.9316 \\
\hline
\end{tabular}




\begin{tabular}{|l|r|r|r|r|r|}
\hline Elymus condensatus & Treatment & 2 & 17 & 0.98 & 0.3963 \\
\hline Encelia californica & Treatment & 2 & 17 & 5.76 & 0.0123 \\
\hline fasciculatum & Treatment & 2 & 16 & 0.33 & 0.7236 \\
\hline Erodium cicutarium & Treatment & 2 & 17 & 0.27 & 0.7659 \\
\hline Eschscholzia & & & & & \\
\hline californica & Treatment & 3 & 22 & 3.13 & 0.0462 \\
\hline Lupinus bicolor & Treatment & 2 & 16 & 1.95 & 0.1746 \\
\hline Lupinus succulentus & Treatment & 2 & 17 & 2.85 & 0.0856 \\
\hline Malosma laurina & Treatment & 2 & 17 & 3 & 0.0765 \\
\hline Penstemon spectabilis & Treatment & 2 & 17 & 3 & 0.0765 \\
\hline Peritoma arborea & Treatment & 2 & 17 & 1.43 & 0.2673 \\
\hline Phacelia cicutaria & Treatment & 3 & 23 & 8.45 & 0.0006 \\
\hline Rhus integrifolia & Treatment & 2 & 17 & 1.54 & 0.2418 \\
\hline
\end{tabular}


Table 4. Relationships between variables amongst species. Results showing how percent germination varies by treatment, functional groups, and provenance.

\begin{tabular}{|c|c|c|c|c|c|c|}
\hline \multicolumn{7}{|c|}{$\begin{array}{l}\text { A. Results from ANOVAS testing relationships between mean germination timing (MGT), } \\
\text { mean percent germination (MPG), the functional group to which species belong, and their } \\
\text { provenance. }\end{array}$} \\
\hline Variable & Source & $\mathrm{DF}$ & SS & MS & $\mathrm{F}$ & $P$ \\
\hline \multirow[t]{3}{*}{ MGT } & Treatment & 2 & 4.77 & 2.39 & 0.07 & 0.9288 \\
\hline & FunctionalGroup & 2 & 636.69 & 318.34 & 9.86 & 0.0003 \\
\hline & Group*Treatment & 4 & 33.34 & 8.33 & 0.26 & 0.9031 \\
\hline \multirow[t]{3}{*}{ MPG } & Treatment & 2 & 0.10 & 0.05 & 0.34 & 0.7153 \\
\hline & FunctionalGroup & 2 & 0.95 & 0.47 & 3.34 & 0.0442 \\
\hline & Group*Treatment & $\sqrt{V 2}$ & 0.00 & 0.00 & 0 & 1 \\
\hline \multirow[t]{3}{*}{ MGT } & Provenance & $\sqrt{v}$ & 428.54 & 428.54 & 12.2 & 0.001 \\
\hline & Treatment & 2 & 7.68 & 3.84 & 0.11 & 0.8967 \\
\hline & Provenance*Trtmt & 2 & 7.78 & 3.89 & 0.11 & 0.8954 \\
\hline \multirow[t]{3}{*}{ MPG } & Native & 1 & 4.02 & 4.02 & 58.69 & $<.0001$ \\
\hline & Treatment & 2 & 0.11 & 0.06 & 0.81 & 0.4487 \\
\hline & Provenance*Trtmt & 2 & 0.01 & 0.01 & 0.1 & 0.9066 \\
\hline
\end{tabular}

B. Results from an ANCOVA on the influence of mean percent germination (MPG), average seed weight (g), and treatment (control, soil, or PPFM) on the average number of days required for seed germination. 


\begin{tabular}{|l|r|r|r|r|l|l|}
\hline Source & DF & Type III & & & \\
& & & SS & F & P & \\
\hline MPG & 1 & 479.48 & 479.48 & 19.84 & $<.0001$ & \\
\hline Weight_g & 1 & 217.24 & 217.24 & 8.99 & $\mathbf{0 . 0 0 4 4}$ & \\
\hline Treatment & 2 & 57.26 & 28.63 & 1.18 & 0.3152 & \\
\hline MPG*Treatment & 2 & 51.48 & 25.74 & 1.07 & 0.3532 & \\
\hline Weight_g*Treatment & 2 & 28.37 & 14.18 & 0.59 & 0.5602 & \\
\hline
\end{tabular}




\section{Figure Captions}

Figure 1: The average number of days that it took for each species to germinate in different inoculation treatments. Species are ordered on the $\mathrm{x}$-axis by the average number of days required for germination in the control group, with bold text indicating non-natives. A. Average $+1 \mathrm{SE}$ of the mean under control conditions. Letters above each bar indicate results of Tukey post-hoc tests, where shared letters indicate no significant difference amongst species $(P>0.05)$. B. Average $+1 \mathrm{SE}$ of the mean under chemical treatments. Asterisks indicate significant $(P<0.05)$ treatment effects. C. The difference in days required for germination in PPFM compared to controls. Asterisks indicate significant $(P<0.05)$ treatment effects. D. The difference in days to germination in the soil treatment compared to controls. Asterisks indicate significant $(P<0.05)$ treatment effects. Full species names are provided in Table 1.

Figure 2: The average percent germination for each species in different inoculation treatments. Species are ordered on the $\mathrm{x}$-axis by the average percent germination in the control group, with bold text indicating non-natives. A. Mean $+1 \mathrm{SE}$ of the mean $\%$ germination under control conditions. Letters above each bar indicate results of Tukey post-hoc tests, where shared letters indicate no significant difference amongst species $(P>0.05)$. B. Mean $+1 \mathrm{SE}$ of the mean $\%$ germination under chemical conditions. Asterisks indicate significant $(P<0.05)$ treatment effects. C. The difference in percent germination in PPFM compared to controls. Asterisks indicate significant $(P<0.05)$ treatment effects. D. The difference in percent germination in the soil treatment compared to controls. Asterisks indicate significant $(P<0.05)$ treatment effects. Full species names are provided in Table 1. 
A. Control

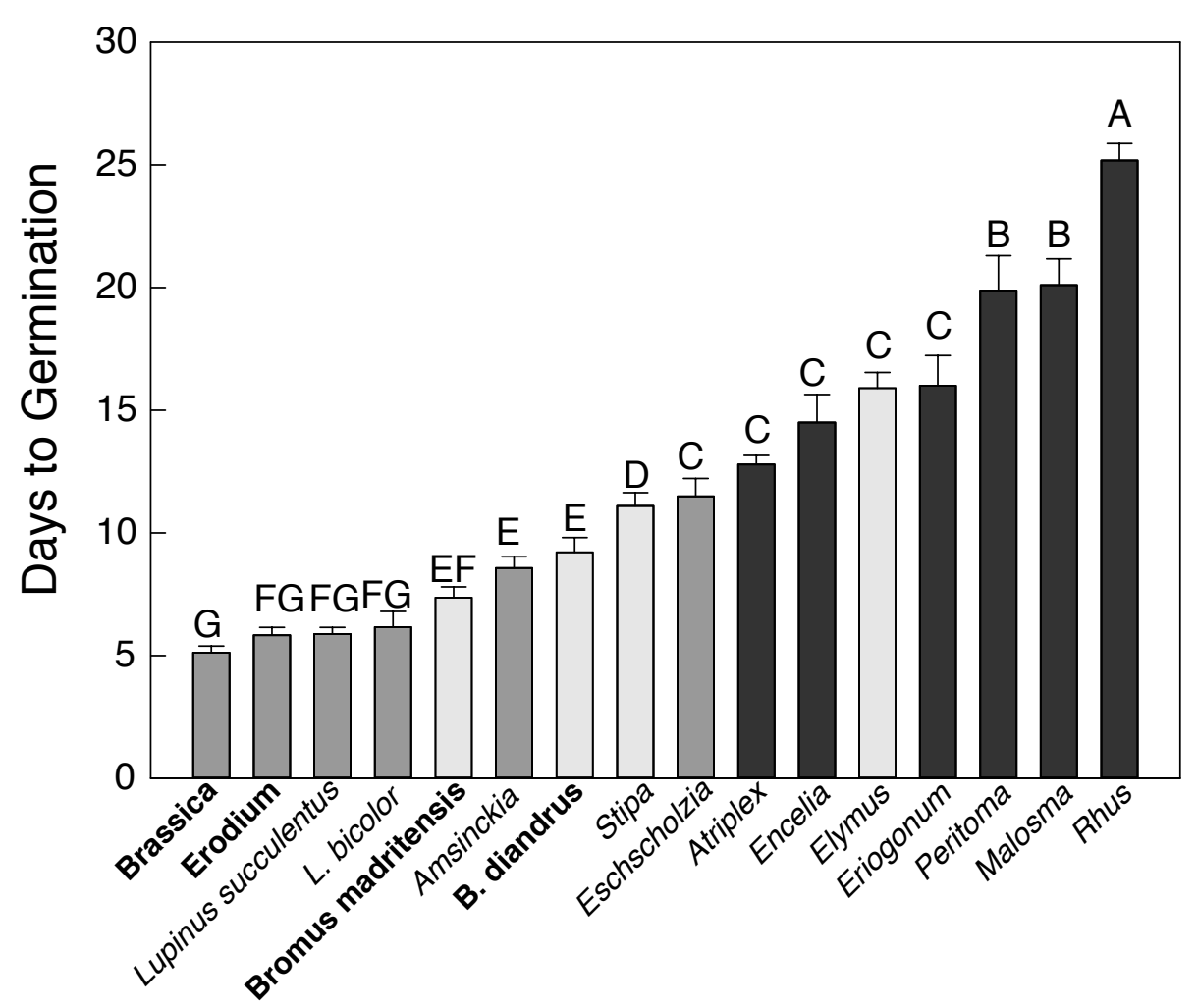

B. Chemical

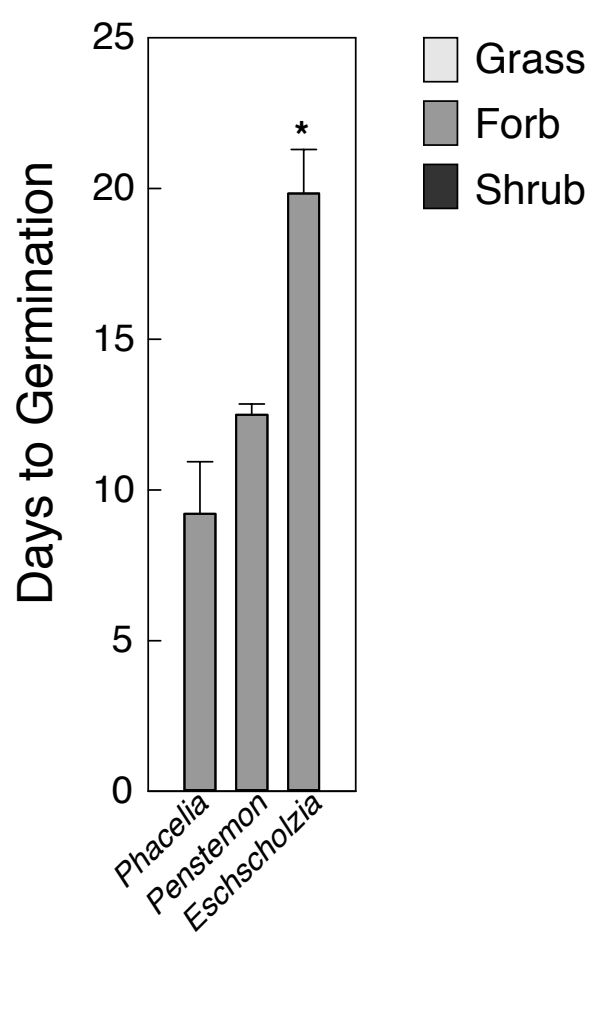

C. PPFM

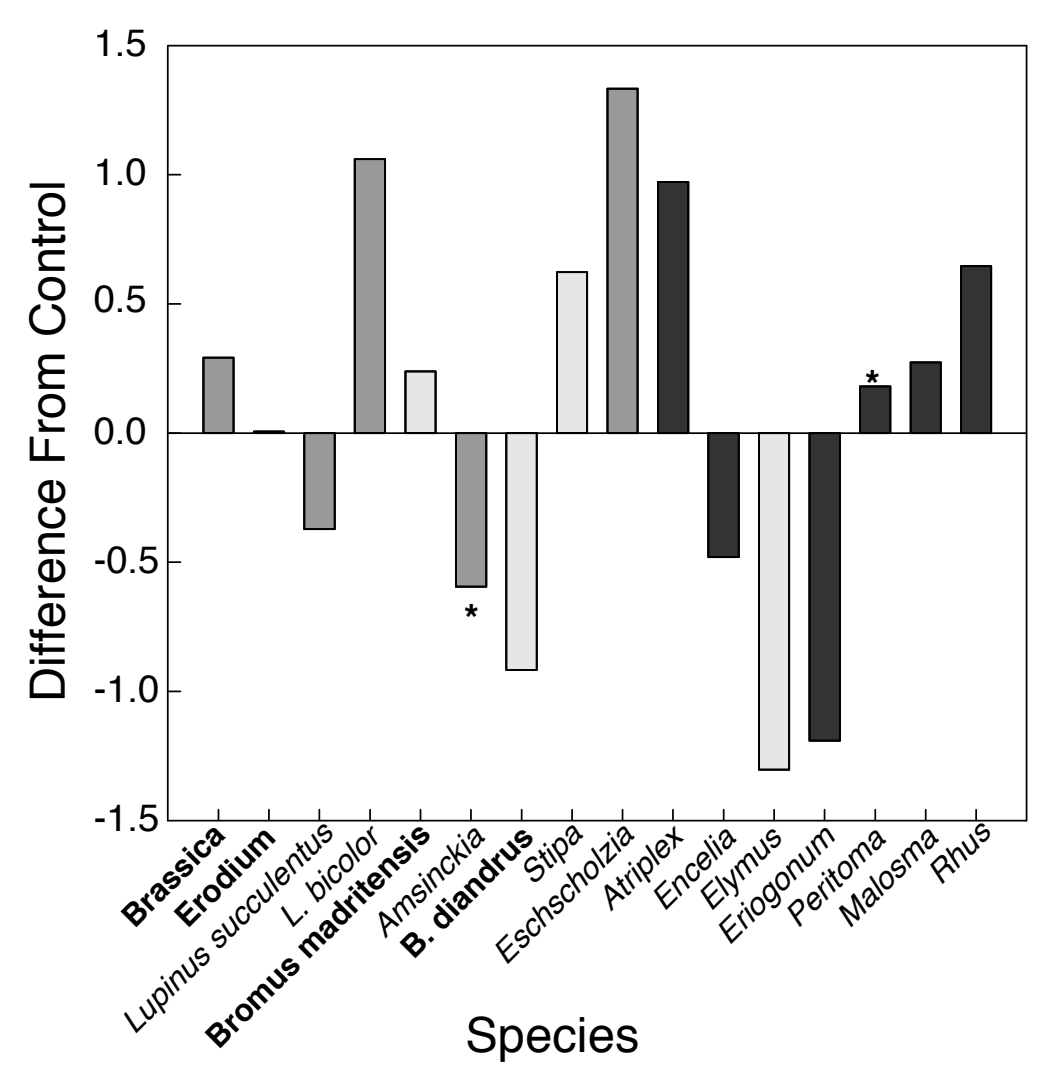

D. Soil

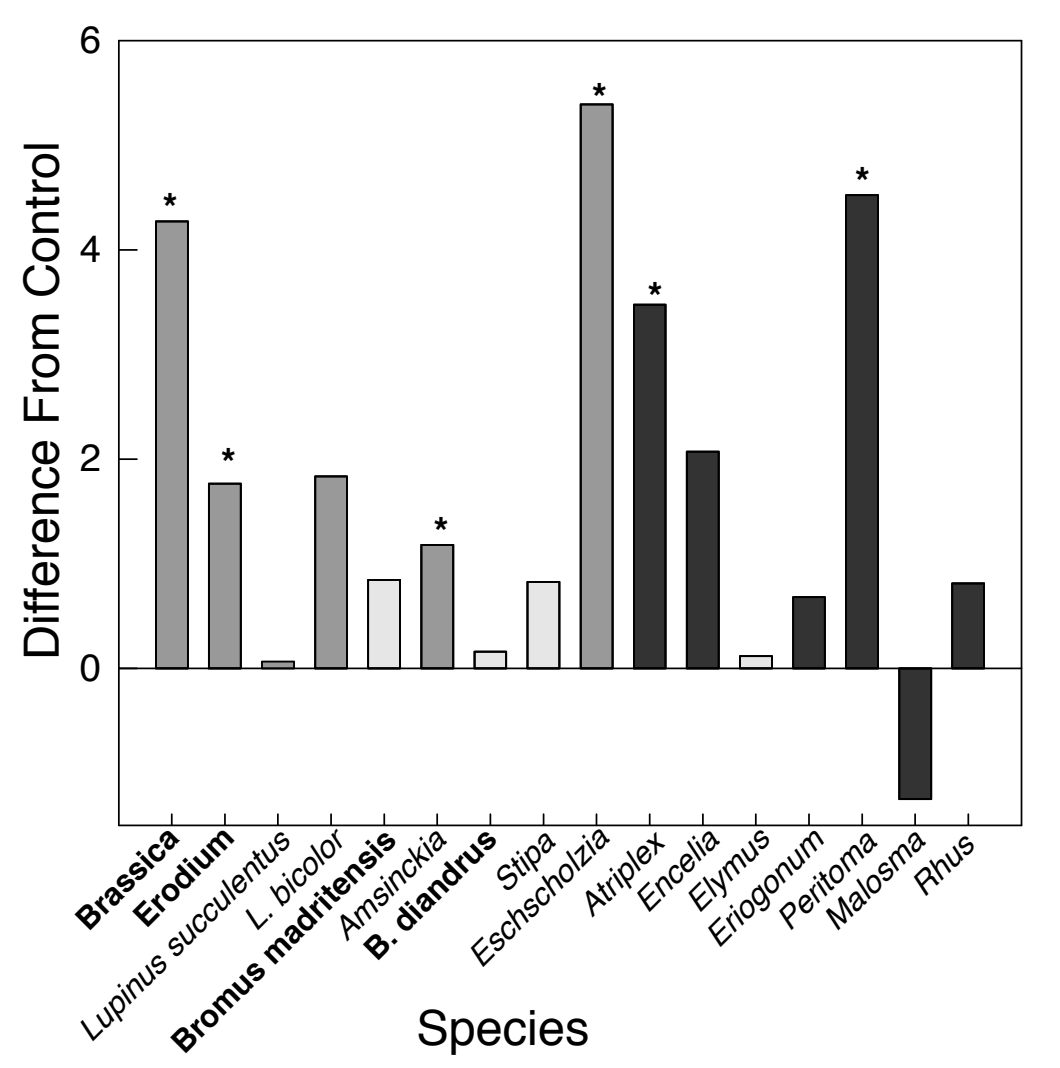


A. Control

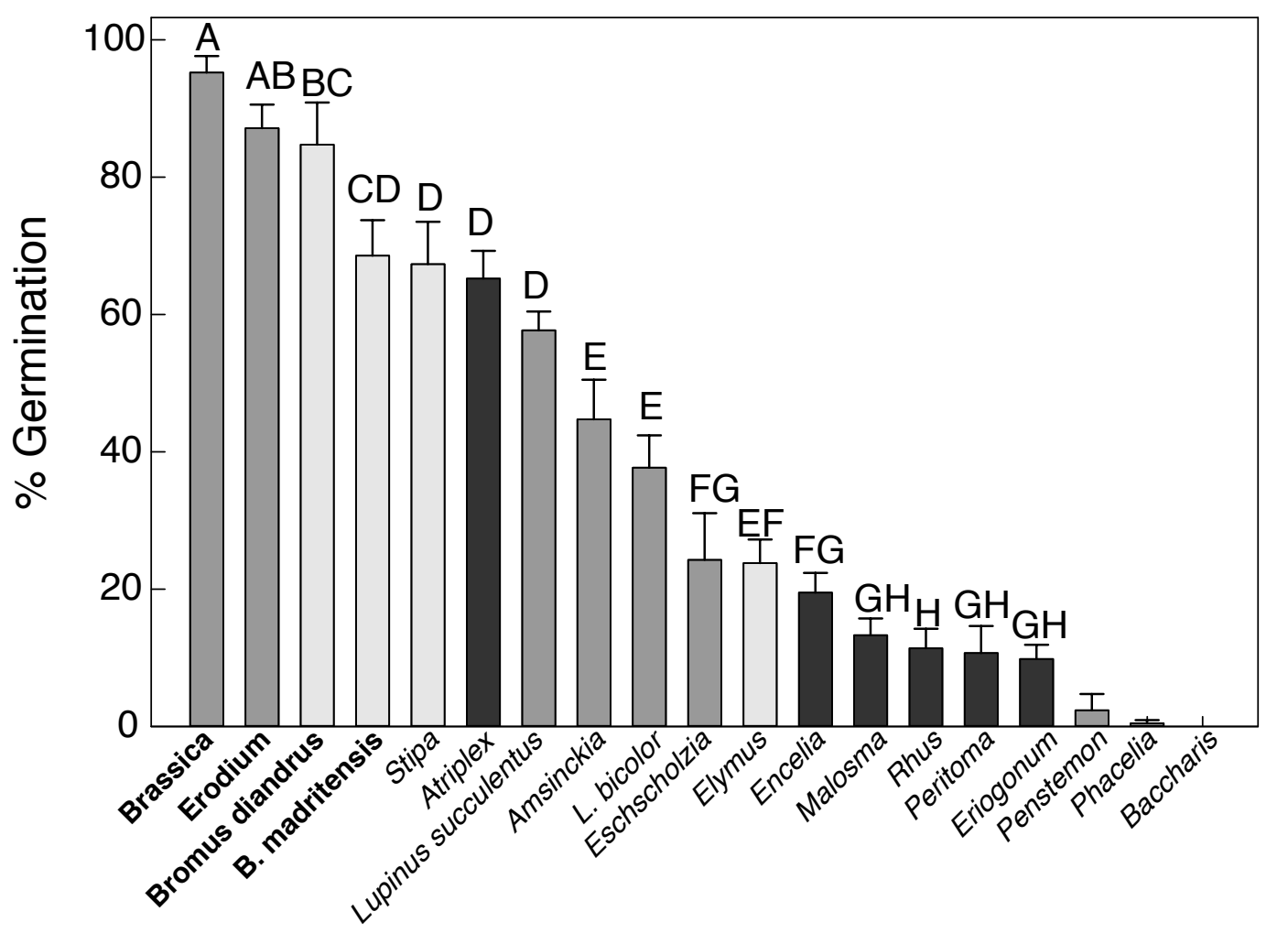

B. Chemical

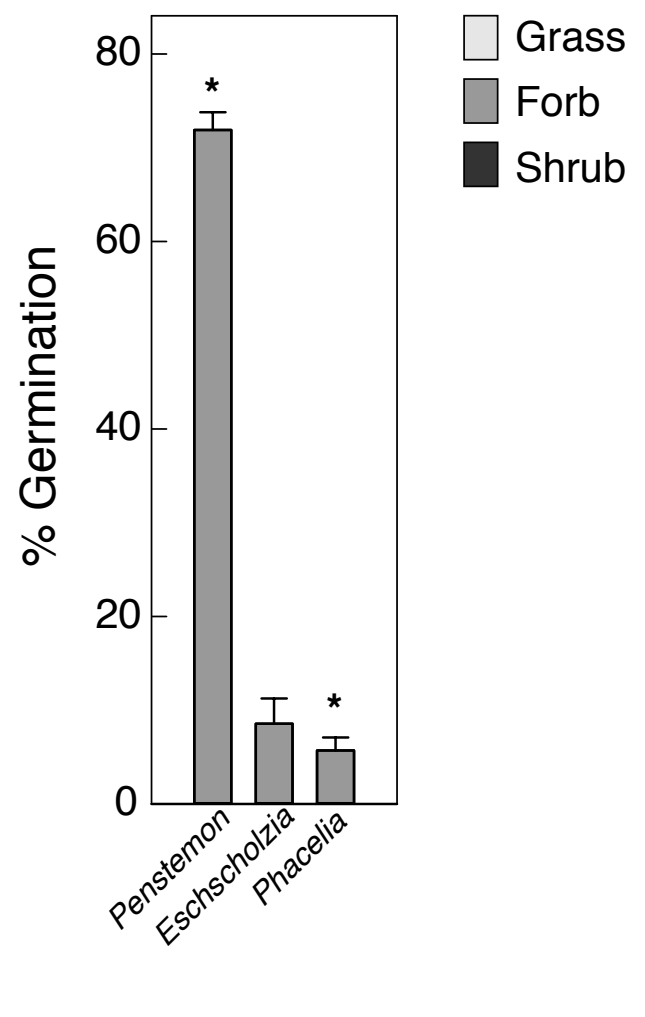

C. PPFM

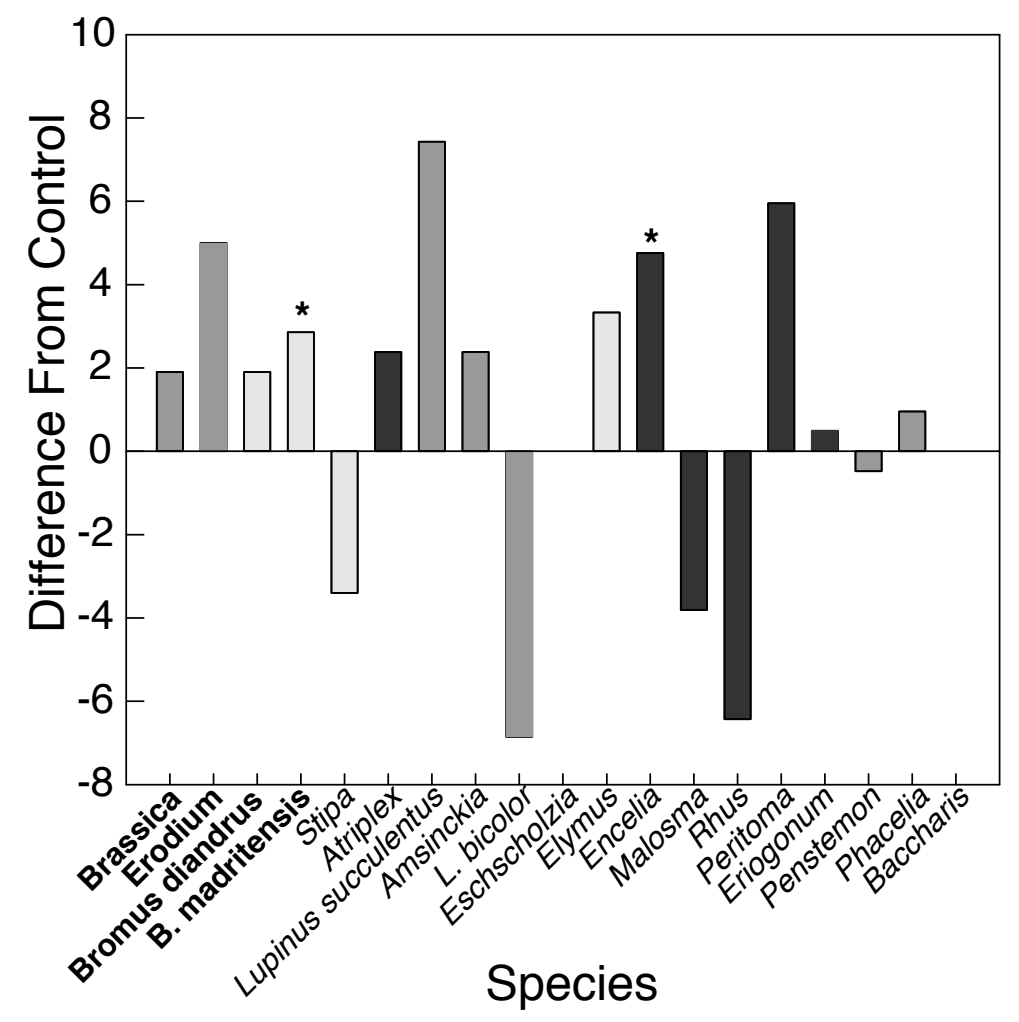

D. Soil

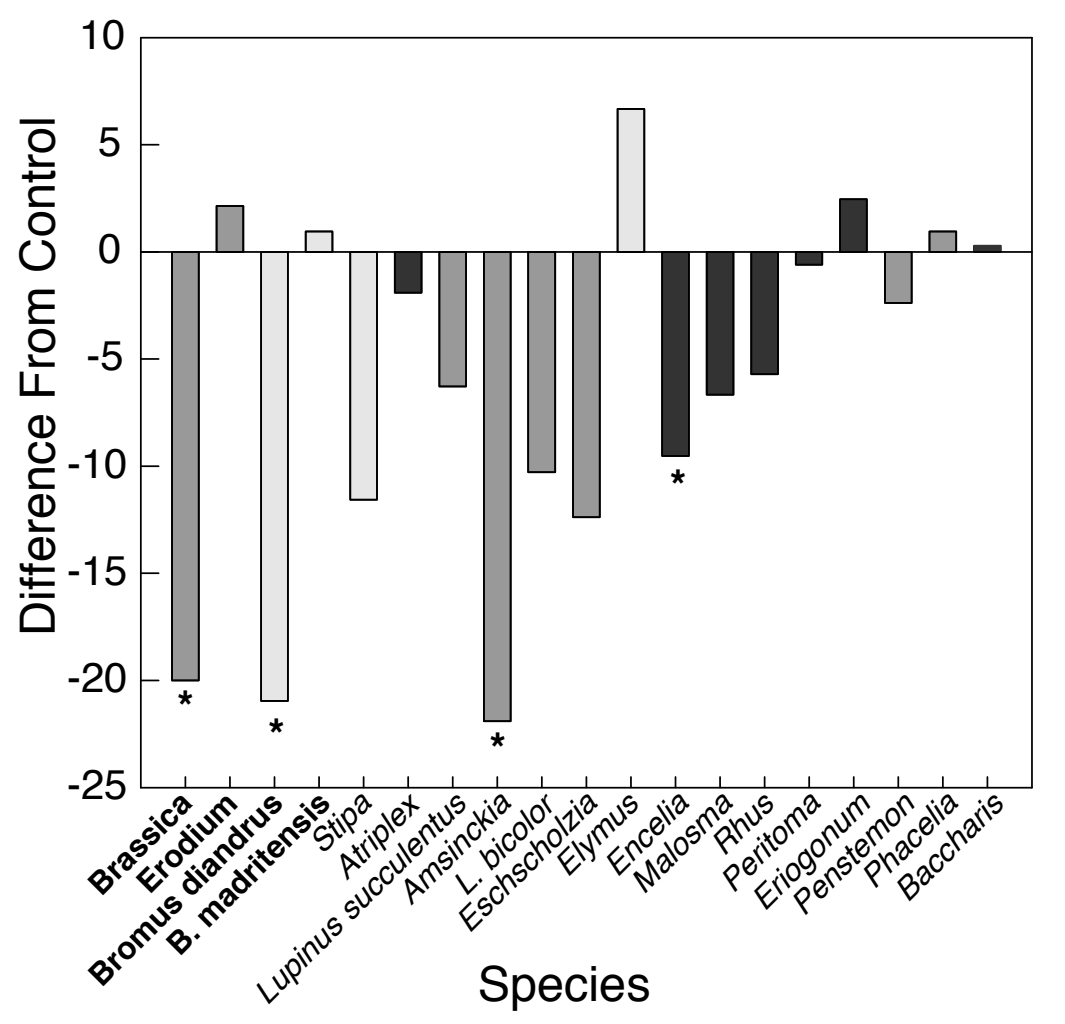

